\title{
"To Have Better Than What I Had": The Transgenerational Family Pedagogy of an African American Family in the South
}

\author{
Jessica S. Powell \\ Southern Connecticut State University \\ Connecticut, USA
}

\begin{abstract}
This paper, based on an ethnographic study of Black families in the South, explores the narratives of the Jordan family across three generations to understand the varied histories of schooling, education, segregation, and desegregation that are embodied in the stories they share. Their stories describe a transgenerational family pedagogy, which I define as the moves, choices, and messages shared across generations to support the educational and social mobility of their children and grandchildren. Their stories underscore the strengths of the segregated community schools of the past, while exposing a shift when de jure segregated education became de facto segregated schooling and was no longer a suitable option for their children and grandchildren. This paper brings a new perspective to the family involvement discourse by arguing that our understandings of family-school partnerships can be strengthened by analyzing families and their relationships to education as historically and contextually situated.
\end{abstract}

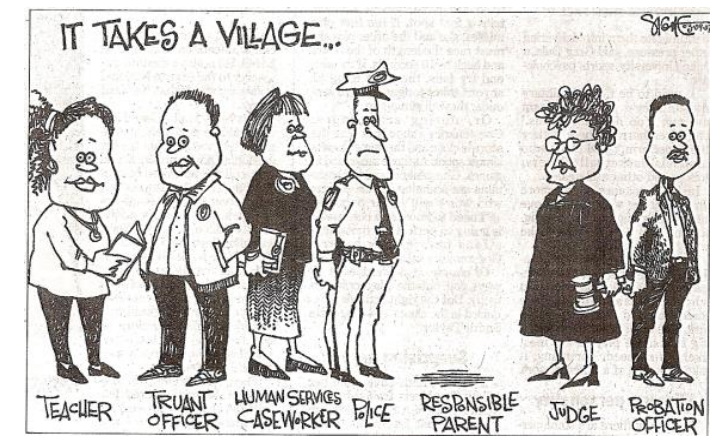

Figure 1. It Takes a Village. News and Observer (2005)

It was 11:30 in the morning when I walked down the hall and into a small, windowless room. I was surrounded by four walls of white cinderblock, a refrigerator, 
sink, and bathroom, all exclusively reserved for teachers. The air was saturated with the smell of melting plastic from the laminating machine. I sat down and began to unpack my lunch; with only 15 minutes to eat I had to be quick. I looked down on the table and noticed a cartoon (above) from the daily newspaper laid out in the middle of the table with a yellow post-it note beside it that read, "So true!" I took the newspaper clipping, folded it, and slipped it into my pocket.

I came across the above cartoon during my second year of teaching at a de facto segregated, predominantly African American and Latino/a elementary school in the southeastern United

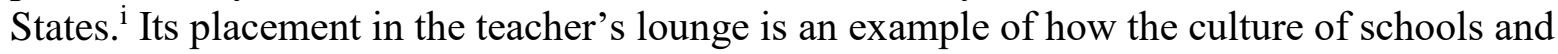
popular media reinforce the image of certain parents as uninvolved or unconcerned with education. It also reflects the growing assumption of the families' responsibility in the educational achievement of their children. Teachers, administrators, politicians, and scholars continue to echo one another, emphasizing the importance of parent involvement in a child's academic success. However, the predominate discourse within education policy and research frequently focuses on the perceived under-involvement and deficit perspectives of many families of color (Baquedano-Lopez, Alexander, \& Hernandez, 2013; King, 2014; Nakagawa, 2000). Moreover, research on family-school partnerships regularly addresses strategies to increase levels of involvement, but fails to provide a textured narrative of a community's relationship with schooling over time. Thus, African American communities are often perceived as uninvolved, disadvantaged, or at-risk.

Gerardo Lopez (2001) urges scholars to move away from this deficit view of families of color toward reconceptualizing family involvement through a more culturally responsive lens. Lopez suggests that families who have been disenfranchised by the system of schooling may be involved with their children's education in ways that are not transparent to, or valued by, many educators. Given our nation's persistent de facto segregated system of schooling and a teaching force that remains largely homogeneous (white and female), there remains a dire need for deeper understandings of and culturally responsive partnerships with families of color.

Heeding Lopez's call and building upon the evolving critical body of scholarship on family-school partnerships (Auerbach, 2007; Baquedano-Lopez, Alexander, \& Hernandez, 2013; Moll, Amanti, Neff, \& Gonzales, 2005; Waters, 2015; among others), this paper brings a new perspective to the family involvement discourse by arguing that our understanding of familyschool partnerships can be strengthened by analyzing families and their relationships to education as historically and contextually situated. This paper challenges the image of family in policy and practice, which is largely ahistorical, by suggesting that families of color have deep histories which they bring to the instrumental demands of educational policy.

Based on a year-long ethnographic study of cross-generational oral histories shared by African American families in the South, this paper explores the narratives of the Jordan family across three generations to understand the varied histories of schooling, education, segregation, and desegregation that are embodied in the stories they share. ${ }^{\text {ii }}$ While the experiences of the Jordan family are unique, they also reflect patterns of race and family-school dynamics evident in our culture and society. Their stories describe a transgenerational family pedagogy, which I define as the moves, choices, and messages shared across generations to support the educational and social mobility of their children and grandchildren. This pedagogy has enabled the families to navigate de jure and de facto segregated communities in hopes of a better future for themselves, their children, and the generations to follow. The stories in this paper reveal how 
family involvement in education takes many forms, including actions and messages that are rooted in transgenerational histories.

The Jordan family's transgenerational pedagogy, shared within largely segregated communities before and after Brown v. Board of Education, protected them from some of the oppressive conditions that many desegregated schools and communities faced. Their stories underscore the strengths of the segregated community schools of the past, while exposing a shift when de jure segregated education became de facto segregated schooling, and was no longer a suitable option for their children and grandchildren.

Mwalimu Shujaa (1994) provides an important framework for the families' critique, in delineating a distinction between schooling and education. Schooling can be defined as, "a process intended to perpetuate and maintain society's existing power relations and the institutional structures that support those arrangements" (p. 15). In the case of schooling in the United States, the epistemology and values that are transmitted are those held by the dominant class, e.g., white Anglo-Saxon Protestants. Education, on the other hand, is defined by Shujaa as:

The process of transmitting from one generation to the next knowledge of the values, aesthetics, spiritual beliefs, and all things that give a particular cultural orientation its uniqueness. Every cultural group must provide for this transmission process or it will cease to exist. (p. 15)

Therefore, while white European-American students may experience education in schools, African American students are more likely to experience schooling since their home cultural orientations are often not represented in the classroom or curriculum. This paper intends to explore this distinction by widening the scope of what constitute educational experiences in the home and community through an analysis of transgenerational family pedagogy.

\section{Conceptualizing Transgenerational Family Pedagogy}

Transgenerational family pedagogy refers to the moves, choices, and message shared across generations. Kabuto (2015) describes transgenerational learning as knowledge that is reciprocal and fluid:

Replacing intergenerational, the term transgenerational refers to the stance that learning and knowledge transcends generations and is influenced by factors that cross space and time. Within this model, parents and their children engage in reciprocal socialization, as there is a constant movement of ideas and knowledge within families as both the parents and their children co-construct learning contexts (p. 46).

Transgenerational, rather than intergenerational, emphasizes the multidirectional movement of experiences within families. For the Jordan family, their pedagogical moves impact not only the educational mobility of the younger generation, but the elder as well.

My theorizing of transgenerational family pedagogy was inspired by Freire's (2005) critical pedagogy, Hughes' Oppressed Family Pedagogy (2005; 2006), and Philipsen's (1999) concept of mothers and grandmothers as dreamkeepers, "who keep alive the dream that education is the harbinger of a better future" (p. 37). 
Pedagogy is more than a method or strategy for teaching. Rather, pedagogy is a philosophical, political, and social act that is anchored in transformation and justice (Freire, 2005). Hughes (2005), building from Freire's critical pedagogy, defines Oppressed Family Pedagogy, as the "intergenerational art of critical and reciprocal teaching and learning that is engaged by families battling oppression" (p. 51). The families in Hughes' study embodied an Oppressed Family Pedagogy by first recognizing their struggle, then developing discursive strategies to combat the structures of power and oppression that operate in their communities. Through this oppressed family pedagogy, families passed down messages of resiliency and positivity as well as strategies for accessing systems of support.

Similar to Hughes' emphasis on a pedagogy of hope, Philipsen, in her book Values-Spoken and Values-Lived (1999), illustrates the ways mothers and grandmothers maintain the memory of the strengths of their segregated community schools by encouraging their children to succeed, despite the challenges of contemporary schooling for African American youth. For the families in Philipsen's study, the elder generations maintained a sense of hope that a successful education was a path toward social mobility and passed these messages across generations.

Informed by these perspectives, transgenerational family pedagogy, as demonstrated by the Jordan family, is more than just explicit teaching strategies. They are choices, values, and messages that are passed across generations, which embody the possibilities of mobility. The Jordan family pedagogy is moved by processes of hope and friction and contextualized by their memories of the past. Almost four hundred years after the first Africans involuntarily crossed the middle passage, five generations post-abolition and two generations since the legal end to Jim Crow segregation, African American communities continue to instill in their children a sense of hope and commitment to education as an avenue toward mobility and justice. The following stories will reveal how a transgenerational family pedagogy enabled the Jordans to navigate $d e$ jure and de facto segregated communities in hopes for a better future for themselves, their children, and the generations to follow.

\section{Methodology}

The methodology used in this study draws from historical ethnography and oral history traditions. Historical ethnography refers to inquiry that seeks to understand the value of historical and cultural events on people's lives (Siddle Walker, 1996). Oral history is a methodology commonly associated with research on African American experiences; however, it has less often been used to explicitly understand contemporary relationships between families and schools. Grele (1975) suggests, "Oral history should be a way to get a better history, a more critical history, a more conscious history which involves members of the public in the creation of their own history" (p. viii).

Informed by the methods of historical ethnography and oral history, I use the lens of historicity to better understand the Jordan family stories. Through historicity, human experiences are understood as a dynamic flow of past, present, and future (Hirsch \& Stewart, 2005). Thus, family stories are not merely a collection of past moments, but exist in a dynamic flow of time and place. Throughout this paper, I use the term family stories intentionally. History, when distinct from story, becomes an accumulation of facts in linear form with an emphasis on Truth (Minh-Ha, 1989). However, history that is contingent on our stories reflects truth as local and interpretive. Minh-Ha (1989) writes that the earliest known stories were memories "transmitted from mouth to ear, body to body, hand to hand" (p. 121). While history aims to inform us as to 
what happened at a particular time and location, stories allow us to experience events sensually and ephemerally in an unspecified time and place (Minh-Ha, 1989). The stories of the Jordan family, intentionally represented in this paper through extensive blocks, invite the reader to experience their narratives and explore how historicity weaves through the intersection between families and schools.

\section{Field Work and Analysis}

Three members of the Jordan family, ranging from six to seventy years old, participated in the study (see Figure 2). Participants were recruited by community nomination (Foster, 1997). After speaking with some members of the community about this project, they referred me to the families who ultimately agreed to participate. The Jordan family currently identifies as middle class, but their narratives revealed their movements across socio-economic brackets and communities, from their early years as sharecroppers to more recent middle-class status. Over a year-long period I met with the first- and second-generation participants three times each and the third generation twice. The third interview was a family story-sharing event where the whole family gathered to share and reflect on one another's stories. Each interview lasted approximately two hours. Interviews took place in the home of the participants, often around a kitchen table. The Jordan family also frequently shared artifacts such as photographs, letters, and books which were included in the analysis.

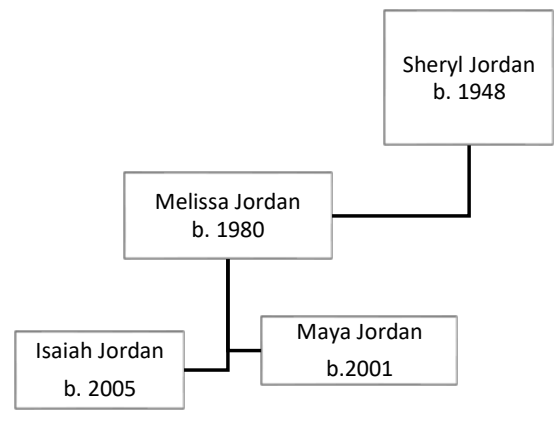

Figure 2. Jordan Family Participants

After completion of the interviews I transcribed and coded each transcript through an iterative analysis process: coding, rethinking, rereading and coding again. Informed by the multigenerational qualitative methodology described by Collins (2011), interviews were coded thematically by participant as well as across generations. One major narrative, or overarching storyline, emerged that became the focus of thematic coding: the narrative of social and educational mobility shared across generations through a transgenerational family pedagogy. Upon completion of a thematic cross-generational analysis, participants' narratives were organized based on theme, rather than their chronology or the order in which their stories were originally shared. This process is referred to as re-storying (Connelly \& Clandinin, 1990). As a method of member checking, I asked participants to read their stories and share with me their questions, comments, and suggestions, paying particular attention to how I reconstructed their stories thematically. Their comments have been integrated into my interpretations and analysis.

Based on this analysis, the stories revealed a transgenerational pedagogy aimed toward upward social, economic, and educational mobility. The following four themes embodied in their family pedagogy will be explored in this paper: 1) moving up through moving toward; 2) moving 
up through family, school, community bonds; 3) moving up through transgenerational messages; 4) moving up through school choices.

\section{Positionality}

As a white, female researcher transplanted from the northeast, I interrogated the interaction of my positionality with the participants and their narratives. Acknowledging the historic tensions of being a white researcher studying African American families in the South, I recognize that the stories told here may not always reveal the hidden transcript (Scott, 1990). ${ }^{\text {ii }}$ Scott (1990) differentiates between public and hidden transcripts as a way to make sense of the stories told and untold between the oppressed and the oppressor. I believe my participants were always cognizant that they were sharing their stories with an outsider; however, there may have been times that we experienced an alliance against larger institutionalized oppressors, allowing for moments of hidden transcripts to emerge. Thus, the analysis to follow recognizes that their stories are incomplete, revealing only the fragments shared by the Jordans, while many others remain untold.

My analysis and representation of my participants' stories recognize the complicated role of interpretation in qualitative research. Although the narratives shared in this paper are in the words of the participants, I must acknowledge my role in their representation. As Minh-Ha (1989) reminds us, "no repetition is identical." Dennis Tedlock (1990) argues that text and interpretation are inseparable. The story being retold is already interpreted through the ethnographer. Furthermore, their narratives, as they are read, will take on new meanings as the readers bring with them their own histories, stories, and understandings (Ellis, 1993).

\section{Geopolitical Context}

Parrish City is a medium-sized city in the southeastern United States. In many ways its history reflects the patterns of race, class, and urban renewal that play out in cities across the country. Of particular interest is Parrish City's rich history of a powerful Black elite class and business community, which thrived during the early twentieth century. Later, the city's plan for urban renewal, as well as the construction of a major highway through a historically Black neighborhood, displaced residents and exacerbated the city's growing number of families in poverty.

Just as there were tensions across social class, Parrish City experienced unequal distribution of resources among its de jure segregated schools. Although a small number of African American students integrated into predominantly white schools shortly after the Brown v. Board decision of 1954, Parrish City did not officially mandate desegregation until 1969. Now, almost sixty years after the Supreme Court decision, Parrish City continues to experience de facto neighborhood and public school segregation, as well as a growing number of charter, independent, and religious schools.

\section{The Transgenerational Pedagogy of the Jordan Family}

In the sections to follow, I have represented the Jordan family narratives as uninterrupted stories taken from their transcripts, allowing their words to take on new forms and understandings as they move from "voice to ear to hand to eye" (Tedlock, 1990, p. 133). Although the stories shared below focus on the narratives of Sheryl and Melissa, their stories 
address the lives of the youngest generation, Maya and Isaiah, and describe how the transgenerational pedagogy continues to move through them.

The Jordan family narratives reveal their memories of segregated schools as places where teachers were passionate and invested. However, their stories of the past are positioned as a critique of contemporary schools. This critique describes schools as spaces where children of color are "marked," and teachers and families are disconnected. Sheryl and Melissa's positive memories of growing up, paired with their critique of public schools today, come together to inform their educational choices and values for the third generation. The family's geographical moves, messages, and commitment to education are all rooted in a common ideal of hope for the next generation, in the words of Sheryl Jordan, "to have it better than we had."

\section{Moving up Through Moving Toward: Sheryl's Story}

I was born in 1948 in a very small rural community about one hundred miles east of Parrish City, called Smithville. We were sharecroppers. We grew up being farmers or sharing the crops with regards to the labor and I guess took the proceeds-if there were any - at the end of the year. A big yard with pecan trees in the back. But I tell you, when nightfall came it would be black as night. The only lights you saw were cars that would go by periodically and you'd look out the window, and because we lived up a lane we would be mesmerized. It was always like, "There's one!"

Having a family of all girls, however, did not excuse us from working hard. The landlord didn't care that you were all girls, you were sharecroppers. So you were expected to do your share of the labor. We were poor. We were farmers. Now, poor by society's standards. But by our standards we were very rich. We were wealthy. We never went without food; we never went without clothing; we never went without a whole lot of love from especially our mom. We worked the farm because that's what we knew to do. We didn't know we were poor. I didn't know anything about an allowance. Never had a need for money. Seriously. I know that sounds crazy but, where you gonna go to spend it?

After separating from my husband I felt that I had to get out of Smithville. It was an opportunity for me to leave, and little did I know it was the beginning of a lifechanging experience for the better. So, I have no regrets. I look back on it as the perfect thing to happen to get me out of my comfort zone and to just basically move on.

My daughter, Melissa, was five when we first moved to Parrish City, to a neighborhood called Magnolia Gardens. A few years after living in Magnolia Gardens we moved out of the city center. I guess you could say that crime is a factor. The quality of the folk who lived in those townhomes when I was there started moving out gradually, and the property value and the upkeep just started going downhill. There was a [housing] project back there, and there was crime in that area. As a matter of fact, my oldest daughter was a victim of an attack on our stoop. I was upstairs, and I heard the key in the door, and then all of the sudden I heard this gosh awful screaming and June ended up falling into the door. The door opened and she fell in and she said that she had just been attacked. It was time to go.

After leaving Magnolia Hill, we moved to Deer Run, a suburb outside the urban area of Parrish City. The folks took pride in their property, and I've always taken pride in mine. There were only three Black families over there and everybody else was White. But same problem as with Magnolia Hill. Somehow or another I missed it. They said that 
a flyer was put in our mailboxes to let us know that a development was coming in behind us. I must have missed the flyer. And because I did not get that notice that everybody else got for whatever reason, the White families started moving out when the construction started. You understand what I'm saying? So, they started moving out. And one day I was home alone and the doorbell rang and I wasn't about to open that door, but I did go to the kitchen and I looked out and I could only see a shadow, but I could tell that that person was casing the area. It was just eerie. So, I decided I needed to go on now.

Soon after Melissa graduated high school, we left the Deer Run neighborhood and moved here to the Oak Woods subdivision a few miles away. And I've been here ever since. We must have moved four times. But each time, it was an upward move. Now they couldn't understand it then, but I had to put them at ease to say that each move is a better move. You don't just stay in one place. Not when you can do better. So you have to move. And each move has been an upward move. That's just how it is.

It's amazing, June and Melissa are of a different breed. They hate everything about the country. They don't even want to go out there to mow the grass. Not that they have to. But, you can see a transition, you can see where the buck stopped with me. When we go back to Smithville now there is nothing there. The fields where you lived is nothing. I'm pretty sure I've said to them that we used to live here, that there used to be a house here. But they can't visualize it because all they see now is an open field. So the physical part is gone, but the memories are there; for me they're there.

\section{Moving up Through Moving Toward: Melissa's Story}

I remember very vividly. Magnolia Gardens was a predominately Black community. When I think about the neighbors that I've interacted with I don't remember there being any Caucasian neighbors at all over there. It's funny, maybe like after the first or second year that we lived in Magnolia Gardens, they put this big, huge, probably tenfoot fence behind our townhouses to separate the townhouses from the projects, which I thought was very interesting. When I say huge I mean it was a huge fence. If there wasn't barbed wire at the top, it was definitely a method to say, "Stay out!" And I actually did the majority of my playing in the projects, because my friends from school, fifteen out of twenty probably lived there. So it was a natural gravitation to go over that way after school.

My sister was unfortunately mugged coming into the house one evening and ended up falling on her knee, on the very edge of the brick steps and ended up having to have surgery as a result of that. At that age I don't think I could comprehend what was safe and what was not. I think initially you may have been concerned because a family member was hurt, but I don't think it dawned on me what that meant until I walked downstairs one day and saw a crutch propped against the front door and a stairwell beam so that the door couldn't be opened. Then you realized that something's different.

In 1991, when I was in fifth grade, we moved to Deer Run. Moving from Magnolia Gardens to Deer Run was a dramatic difference. Went from being in a townhome to a single family home. The neighborhood was completely the opposite. We moved from a neighborhood that was engrained in the heart of a community to one that was off in the suburbs. Over the course of the ten years we lived there it had turned to a predominantly Black neighborhood with maybe only one White family there, and they lived at the very outskirts of the community. You could see more kids playing outside, so 
for me it was kind of like attracting the same people that I played with when we lived in Magnolia Gardens. Even though we were in different communities, they had the same mentality, they lived similarly, they talked similarly, but then it got to the point that we started hearing gunshots at random. I'll never forget it, it was eleven o'clock at night and a lady came to the door and she was trying to sell car air fresheners. At that point Mom was like, "Yeah, it's time to move."

The geographical moves the Jordan family made were an integral element of their transgenerational family pedagogy. Sheryl moved her family from the rural country to the inner city and finally to a suburban neighborhood. In each of these neighborhoods, segregation persisted and poverty and crime continued to seep into their communities; however, Sheryl and Melissa continued to view each move as an upward move.

After carefully attending to the meanings my participants ascribed to their experiences, it was clear that they were not moving solely away, but rather moving toward. This distinction is important because it resists the dominant tendency to name their original home as a place from which to escape: the language often applied to families in poverty within mobility literature and policy. For example, Sheryl Jordan's description of her life as a sharecropper emphasized the strengths of growing up on the farm. When describing her mother's biscuits, their hard work in the field, and the peaceful darkness of rural nighttime, her eyes would close as if momentarily visiting her childhood home. For Sheryl, leaving Smithville for Parrish City was in many ways an upward move, but it was moving toward some other opportunity, rather than moving away. Similarly, although Melissa acknowledges the tensions in her childhood community, she also highlights the strengths of her segregated community.

For Melissa and Sheryl, navigating their neighborhood spaces in search of communities where they felt safe and proud was a response to the frictions they experienced, such as the specter of violence in their neighborhoods, as well as their forward gaze. Movement suggested possibilities and opportunities not just for themselves but for their children and the generations not yet born.

\section{Moving Up through Family, School, Community Bonds: Sheryl's story}

Back in Smithville, we had to walk a mile to catch the bus. We had to do that for several years and I can recall one summer, we were working in tobacco, just as clear as day I can see it right now, the principal paid a visit to the farm. I can recall, that man had on some brown and white shoes and he put his foot up on the tobacco cart, gentlemanly like, and he wanted my mother to know that when school started in September that the bus would be coming down the road to pick us up. She hugged that man. She was so excited, because bad weather or whatever we had to walk that mile to get to that bus.

The teachers, oh my God, they took pride in their work. Oh you're talking about a village! Not only did the teachers like me, all of the teachers liked my mother because they knew she was a lady that was about something and worked for the good of everybody. I'm very serious about that. They respected her so much they would actually visit our homes some evenings just to sit and talk and laugh with my mother. No reason other than just to socialize. She was something else. My mother was a standout. My mother was PTA president. She was a mover and a shaker in the community. I lie to you not. That woman had some staying power. To this day, she is still something. She told us, all seven of us, that she wanted us to have things better than what she had when she was 
coming up. I followed in my mother's footsteps, I was PTA officer, involved in anything they were involved in, didn't miss one play, not one. You name it, I was there to give them support.

\section{Moving Up through Family, School, Community Bonds: Melissa' Story}

Elementary school at Sampson Hill was very comfortable for me. It was a rowdy environment but it wasn't out of order. I knew everyone by name. The teachers were very much involved in what you were doing. I remember having my fourth grade teacher who brought me in, Ms. Williams. She would take in young girls to cultivate them and spend time with them, like a big sister. She actually let us sleep over, she ordered pizza and snacks and she actually did a debutante-type program for young girls where she was my sponsor.

Back when my mom was in school, it was family, school, and church. I think in the traditional African American community, it was common for the teacher to have taught your mom and your dad and your grandma, so they knew about your family. They knew your parents. So they had expectations of what you should be able to do because they helped to plant that seed in those that bore you. Their teachers disciplined very strong, straightforward, and stern. But they also cared. If you did something wrong, they would spank you in school and then tell your mom that they spanked you and then you would get another one when you got home! But then they were the same people that you saw in your church; they were the same people that you saw in your community, at your store, so they were really engrained in that place. It's not like that, not now.

I think the teachers at Sampson Elementary knew what they were dealing with in knowing that they were having children that were coming from not the best economic backgrounds or situations, and so they weren't scared to go into the housing project; they weren't afraid to say, "I'll take you home, it's dark." I think that my class growing up may have been the last branch of that tree where that area of responsibility continued to carry through. So that has broken.

Sheryl Jordan remembers the ways her parents were involved in her education: attending school events, PTA meetings, and involving the family in church related activities. She also remembers the ways in which she was involved in her own daughter's education by attending school events, having relationships with teachers outside of school, and modeling lifelong education and work ethic through her own practices. These memories also highlight the qualities of their teachers who blurred the boundaries between school and community. Sheryl recalls the strengths of her teachers and administrators and the relationship her mother forged with them in and outside of school.

Both Sheryl and Melissa's stories speak to the fluidity of family-school relationships in the segregated communities of the past. Their stories describe the ways teachers and families were threads through the same fabric and how this relationship has changed in contemporary schools. The Jordan family narratives suggest the varied ways their families have been and continue to be involved and invested in education across generations. Not only were parents involved in their children's education, but grandparents as well. Sheryl Jordan, whose daughter and grandchildren often reside in her home, also shared stories of her involvement in and support for their education. The forging of relationships with educators and community members is a value moved across generations through their family pedagogy. 


\section{Moving Up Through Transgenerational Messages: Sheryl's Story}

When I was growing up we were expected to behave a certain way. No fighting, no cussing, no smoking in the streets, no going with married men. Better not come home with bad grades, because we were not dumb kids. No sassing, no talking back. And I will never forget this, and it sticks with me to this very day: Mama taught us early on that all we had was our name and that we had to take care of it. She said to us, "Ya know, when you grow up if you're name is right, you can get just about anything that you want." She said your name stands for something.

One of the things that my sisters and I decided to do, we set up a scholarship fund for children in our home town. The scholarship is to help those kids attend the cultural center there during the summer. We raised funds that allow the kids whose parents can't afford it to go to the camps during the summer to get them off the street. But it's all in honor of my mother. It's called the Simone Collins Youth Camp Assistance Fund, after my mother.

My mother was something else. Back in those days they weren't educated. My daddy didn't even get to the third grade; he could not read or write. My mother got as far as the eighth grade, but did not finish. So, back then I had a job working as a recruiter with the Smithville Community College to encourage folks to complete their GEDs, and my mother was the second person I recruited - I was a recruiter for that program. When Smithville Community had its graduation they marched because they completed their GEDs. And they had the caps and gowns on and everything. You would have thought she had gotten her Ph.D.

\section{Moving Up Through Transgenerational Messages: Melissa's Story}

My mom encouraged me to really value who I was, "cause back in elementary school I had gotten into maybe two or three fights. I remember after fighting I just started crying because I knew that it wasn't me. My mom helped me know that my name was my brand and that's all I had at the end of the day. My mom would always say that. It's gonna be strong or it's gonna be weak based upon what I've done. She would say "Your name is all you have. So if you don't take care of that then you have nothing." My mom has set the example.

After my mom and dad divorced she came this way and picked up her books and went back to school. When it comes to my job or school those are just things that you just didn't play with, you just knew. My mom's expectations and value system for education was very high. It was never a threat. You just knew. When I was getting my undergrad degree she was getting her Master's. So the expectation was there that you will do better. I always knew to respect my teachers because my mom was always there and if I cut up, I might as well just cut up directly to my mom instead of cutting up to my teacher.

Whether it was through church or a community organization, my mom was involved, so it's funny when I found myself doing the same thing. The way I'm involved, I definitely see my mom in that. But I struggle finding a balance maintaining what I need to do at work and when it's ok to break that and go to my children's school.

Narratives among all the Jordan family reflected the transgenerational pedagogical approach of shared messages that imparted core values and emphasized how family members should represent themselves to society. Jennifer Ritterhouse (2006), in her historiography on how 
Black and White children learned the concept of race in the Jim Crow South, addresses the way Black families taught their children a form of etiquette that countered Jim Crow's disparaging behavioral expectations of respectability. This etiquette was in contrast to the form of respectability designed and enforced by a White, racist society. For example, respectability emphasized proper ways to address White people and racial street etiquette such as not sharing a sidewalk with a White person. She explains that many Black families tried to shelter their children from the symbolic violence of racism by "teaching them to maintain a dignified public persona, and with it, their self-respect" (p. 19).

For Sheryl, her mother's pedagogy reflected the counter-respectability described by Ritterhouse (2006). These behavioral expectations served a dual purpose, to protect her from the violence of racism and to build her esteem and identity as a strong Black woman. In one interview, Sheryl showed me two faded black and white photographs of her in elementary school in the 1950's. She pointed out her clothing, as well as her classmates' in both photographs:

Look at that picture, look at that whole room. Look at that group. That was the Glee club, but look at those kids. Do they look like they are hurting for anything? Look at 'em! Bowties, beautiful dresses.... Do you understand what I'm saying? Poor and don't even know that you're poor. You don't look poor, you're not acting poor.

While the policies of Jim Crow were abolished before Sheryl's children and grandchildren were born, expectations of how they represented themselves persisted. Melissa's stories reveal the thread of the family message, "your name is your brand," weaved across generations, from her grandmother, to her mother, to her. Her teachers also reminded her to stay rooted in her identity but also be conscientious of how her behavior represents both herself and her Black community

These stories of involvement are a symbol of their investment. For the Jordan family, educational and social mobility has little meaning without continuing this upward movement across generations. But, as described earlier, transgenerational investment is not a linear, oneway process. Younger generations also invest in their elders, cycling back to those who originally invested all of their resources in the hopes of the educational and social mobility of their children. Sheryl Jordan was an integral force in supporting her mother's completion of her GED, a pinnacle moment in her mother's life. Both Sheryl and Melissa reflected on the educational achievements and limitations of their elders in relation to their own achievement, which shaped their family pedagogy to ensure that their children would have more opportunity than they had. The stories of Maya and Isaiah (the youngest generation) suggest the materialization of their elder's hopes and investment. Although they are young and our interviews were limited in scope, their stories of education reveal a pleasure of learning and reading as well as a clear work ethic.

Maya and Isaiah briefly commented on their knowledge of their elders' histories, suggesting a connection to or knowledge of their past, to something bigger than they are. While some of the children spoke "tongue in cheek" about their elders' upbringing - joking about the boring stories of growing up on the farm, playing with marbles, or about how poverty stricken their elders' childhood seemed - the knowledge they have of their roots alludes to conversations that they are having with their elders about the past and how it relates to their lives. These conversations offer a glimpse into the generational tilling of hope and investment that not only ground Maya and Isaiah, but which also will move them toward their future. 
Jessica S. Powell

\section{Moving Up Through School Choices: Sheryl's Story}

When I was getting ready to move out of Magnolia Gardens to my new home, I had to decide what to do about Melissa's schooling; whether or not to take her out of Sampson Hill [predominantly Black school with Black teachers] and move her to a new school, East Parrish Elementary [predominantly White school with White teachers]. I decided I would move her. It was the middle of the school year and so I met with the principal and told her what I was planning to do and she encouraged me. It was just that bad. Melissa was a high-performing child. The principal gave me her blessings and said, "Go." It was a better move because there was some programs at East Parrish Elementary that Melissa got involved in that weren't offered at Sampson at all. The resources were greater at East Parrish than they were at Sampson.

My grandchildren are my priority. At Parrish Christian the classroom size is small, thirteen to fourteen children. Not to mention they were far ahead of the public school. They incorporated scripture, the Bible, into it. They are required to go to Chapel every Monday.

But at Parrish Christian Academy they have the opportunity to be in an environment where they aren't distracted because of one thing and another. They are afforded opportunities they could not have gotten in public schools. I think that the biggest difference is that they are not subjected to a lot of the negative stuff that is in the public school: the gangs stuff, the bad language, the out of control. Not at Parrish Christian.

I am so proud of both my daughters. Because they are making monumental sacrifices for their children, to have better than what they had. And they are just doing what's done onto them. My mother would always say, I wanted you all to have better than what I had. And I wanted June and Melissa to have better than what I had.

\section{Moving Up Through School Choices: Melissa's Story}

I want the best education for my kids. Public school was never an option for my kids. We did look at a charter school, Columbus Charter. Both Parrish Christian and Columbus have very small class sizes, very good teachers who invest in the kids, and of course the athletic and extra-curricular components. If I could get them in a good school where they would be safe and get what they need and not have to pay, that would be a huge bonus.

Would I send them to public school? I went to Parrish City Schools, so it bothers me to say, "No." When you look at the trends you see over the past few years, and testing scores being low, and I actually worked with a group of girls in Columbia High a couple years ago, and seeing the dynamic now compared to when I was in school and looking at my kids, I just said, “Wow, I don't know." I couldn't wrap my mind around that. I want them to be in a place where as a parent I feel secure when I drop them off. That in my heart of hearts, even if something happens I feel confident that the teachers would do what's in the best interest of the kids. And that's what we get at Parrish Christian Academy. Right now my instinct is not to send them to public school.

Of the many choices embodied in transgenerational family pedagogy, one of the most significant ones is the families' decisions where to send their children to school. Both Sheryl and Melissa had positive experiences in their de jure and de facto segregated public schools. 
However, they have chosen to send the third generation to a private Christian academy. The school for which Maya and Isaiah are zoned is a de facto segregated Black and Latino/a school, not far from where Melissa attended elementary school years ago. The memories of the elder generations' education as places of pride and achievement are positioned as a critique of the contemporary state of schooling.

For Sheryl, moving out of Magnolia Gardens (a predominantly Black, working-class neighborhood) to Deer Run (an initially suburban White neighborhood before it re-segregated) was an exercise of school choice. Although Melissa recognized the losses that accompanied this move, in particular the genuine relationships with her Black teachers, Sheryl highlighted the resources afforded by the suburban elementary school. Scholars have recognized a growing trend in Black families taking control over their educational opportunities by removing their children from public schooling and placing them in independent or Christian schools (Shujaa, 1994; Stulburg, 2008). Shujaa (1994) contends that many families of color choose to place their children outside public schools so that they are provided with a competitive education enabling them to excel and achieve success in a perceived meritocracy.

This description seems applicable to the schooling choices of the Jordan family. While recognizing the friction between their own positive history with public education and their critique of contemporary schooling, Sheryl and Melissa are confident in their choice to educate their children outside of the public system as a means of educational mobility.

\section{Discussion}

The Jordan family narratives reveal a transgenerational pedagogy that provides a textured understanding of family involvement in education that is steeped in historicity. The Jordan family's pedagogy, shared largely within segregated communities, protected them from some of the oppressive conditions that many desegregated schools and communities faced. Through various moves, choices, and messages shared across generations, the families ensured that their children and grandchildren could access educational opportunities that were not available to them or their elders. The families also sought educational opportunities which were afforded to them, but are no longer easily accessible in contemporary public schools. The stories address the strengths of the segregated community schools of the past and emphasize a change when segregated public education (either de jure or de facto) became segregated public schooling and was no longer an optimal choice for their children and grandchildren. Furthermore, their school choice carries on the memory of their childhood classrooms as places of possibility that cultivated their mobility trajectories. Pushing back against a system of schooling that may inhibit their children's success, the families have chosen schools that embody the values represented in the education of their past: community, faith, and commitment to education.

This research on transgenerational family pedagogy suggests a reconceptualization of family involvement in education that honors the social, cultural, and historical contexts which families navigate. The Jordan family's strong identity, connection to their past, movements across communities, and the choice not to enroll their children in public school are all forms of their commitment to education. Like a palimpsest, Sheryl and Melissa's childhood schools, family, and community are superimposed onto their hopes for the next generation. 


\section{Conclusion}

By broadening our understanding of pedagogy as transgenerational social, political, and historical acts that can occur beyond the walls of the classroom, we can begin to envision new frameworks for family involvement in education. This work has implications for public school educators and teacher education programs, by emphasizing the relevance of local, historical narratives and counter-narratives in understanding student and family perspectives toward schooling and education. Such historical perspectives of diverse families are often omitted from teacher education curricula. Furthermore, the narratives that emerge from this study may encourage teachers to seek a deeper understanding of their own school community's history in order to appreciate the perspectives and histories of the families they serve.

The cartoon in Figure 1 shows a dark shadow hovering over a void representing the absent parent in a "village." In a twist of the African proverb, the village members in the cartoon resemble more closely players in the school-to-prison pipeline rather than the teachers of Sheryl and Melissa's village decades ago. In an effort to counter the narrative of this new village and the ahistorical view of the absent parent, I urge politicians, educators, and researchers to consider the local and transgenerational relationships among families and schools and reimagine family involvement as a process that inhales and exhales history. 
"To Have Better Than What I Had"

\section{References}

Auerbach, S. (2007). From moral supporters to struggling advocates; Reconceptualizing parent roles in education through the experience of working class families of color. Urban Education, 42(3), 250-283.

Baquedano-Lopez, P., Alexander, R. A., \& Hernandez, S. J. (2013). Equity issues in parental and community involvement in schools: What teacher educators need to know. Review of Research in Education. 37, 149-182. DOI: 10.3102/0091732X12459718

Brown v. Board of Educ., 347 U. S. 483 (1954).

Clotfelter, C. T. (2004). After Brown: The rise and retreat of school desegregation. Princeton, NJ: Princeton University Press.

Collins, D. R. (2011). Conducting multi-generational qualitative research in education: An experiment in grounded theory. New York, NY: Peter Lang.

Connelly, M. F., \& Clandinin, J. D. (1990). Stories of experience and narrative inquiry. Educational Researcher. 19(5), 2-14.

Ellis, C. (1993). "There are survivors": Telling a story of sudden death. The Sociological Quarterly, 34(4), 711-730.

Foster, M. (1997). Black teachers on teaching. New York, NY: The New Press

Freire, P. (2005). Pedagogy of the oppressed. $30^{\text {th }}$ Anniversary Edition. New York, NY: Continuum International.

Grele, R. (1975). Envelopes of sound: The art of oral history. Chicago, IL: Precedent Publishers.

Hirsch, E., \& Stewart, C. (2005). Introduction: Ethnographies of historicity. History and Anthropology, 16(3), 261-274.

Hughes, S. A. (2005). Theorizing oppressed family pedagogy: Critical lessons from a rural black family in the post-Brown south. Educational Foundations 19(3/4), 45-72.

Hughes, S. A. (2006). Black hands in the biscuits, not in the classrooms: Unveiling hope in a struggle for Brown's promise. New York, NY: Peter Lang.

Kabuto, B. (2015). Transgenerational learning within families. Journal of Family Diversity in Education, 1(4), 45-65.

King, J. E. (2014). Black educators for human freedom: Of the African renaissance and history in the present. In I. Nunez, C. T. Laura, \& R. Ayers (Eds.), Diving in: Bill Ayers and the art of teaching into the contradiction (155-166). New York, NY: Teachers College Press. 
Lopez, G. R. (2001). The value of hard work: Lessons on parent involvement from an (im)migrant household. Harvard Educational Review, 71(3), 438-474.

McClatchy Co. (2005). It takes a village. News and Observer. Durham, NC.

Moll, L., Amanti, C., Neff, D., \& Gonzales, N. (2005). Funds of knowledge for teaching: Using a qualitative approach to connect homes and classrooms. In N. Gonzales, L. Moll, C. Amanti (Eds.) Funds of knowledge: Theorizing practices in households, communities, and classrooms (71-88). New York, NY: Routledge.

Minh-Ha, Trinh (1989). Woman, native other: Writing, postcoloniality and feminism. Bloomington, IN: Indiana University Press.

Nakagawa, K. (2000). Unthreading the ties that bind: Questioning the discourse of parent involvement. Educational Policy, 14(4), 443-472.

Philipsen, M. (1999). Values-spoken and values-lived: Race and the cultural consequences of a school closing. Cresskill, NJ: Hampton Press.

Ritterhouse, J. (2006). Growing up Jim Crow: How Black and White southern children learn race. Chapel Hill, NC: University of North Carolina Press.

Scott, J. C. (1990). Domination and the arts of resistance: Hidden transcripts. New Haven, CT: Yale University Press.

Shujaa, M. J. (1994). Education and schooling:You can have one without the other. In M. J. Shujaa (Ed.), Too much schooling too little education: A paradox of Black life in White societies (13-37). Trenton, NJ: African World Press Inc.

Siddle Walker, V. (1996). Their highest potential: An African American school community in the segregated south. Chapel Hill, NC: University of North Carolina Press.

Smallwood, S. E. (2007). Saltwater slavery: A middle passage from African to American diaspora. Cambridge, MA: Harvard University Press.

Stulberg, L. M. (2008). Race, schools, and hope: African Americans and school choice after Brown. New York, NY: Teachers College Press.

Tedlock, D. (1990). From voice and ear to hand and eye. Journal of American Folklore, 134156.

Waters, B. S. (2015). We can speak for ourselves: Parent involvement and ideologies of Black mothers in Chicago. Boston, MA: Sense Publishers. 


\section{"To Have Better Than What I Had"}

\section{Notes}

${ }^{1}$ De jure segregation refers to segregation mandated by law, which ended after the landmark Brown v. Board of Education in 1954. De facto segregation refers to segregation enacted more subtly through policies and social practices (Clotfelter, 2004).

${ }^{2}$ All names and places have been replaced by pseudonyms to protect the anonymity of the participants.

${ }^{3}$ Scott (1990) contends that stories shared by individuals belonging to a subordinate class will "appeal to the expectations of the powerful" (p. 2). He defines public transcripts as "the open interaction between subordinates and those who dominate" (p. 2). Hidden transcripts, in contrast are "the discourse-gesture, speech, practices-that is ordinarily excluded from the public transcript. The practice of domination, then, creates the hidden transcript" (p. 27). 